\title{
Comparison of the Parameters of Thermal Comfort in a House Built With Green Bricks With a Conventional Construction
}

\author{
A. O. Esteves ${ }^{1,2}$ and T. M. Souza ${ }^{1,2}$ \\ ${ }^{1}$ Department of Electrical Engineering \\ UNESP \\ Campus of Guaratinguetá - Av. Ariberto Pereira da Cunha, 333 - Pedregulho (Brazil) \\ ${ }^{2}$ Renewable Energies Center - UNESP (www.feg.unesp.br/energiasrenovaveis)
}

Phone/Fax number:+55 012 31232777, e-mail: es.amanda@gmail.com, teofilo@feg.unesp.br

\begin{abstract}
.
This project consists of the comparison of thermal comfort between a house made of green bricks and a construction made of conventional bricks. The green bricks are made of cement, water and soil and provide many benefits such as: material savings, reduced construction time, is easy to produce and can be done at the construction place and don't consume fuel in the manufacture. At the structure of this bricks, have holes provides thermal and acoustic insulation, doesn't allow the accumulation of moisture on the walls, facilitates the electrical and plumbing systems and promote the engagement of bricks, giving greater symmetry. It is intended to show and prove that this type of brick provides benefits for buildings.

This project used the devices: thermometers with and without contact, anemometer, hygrometer and density meter solar power. With these equipaments are measured internal and external temperatures to buildings and bricks, wind speed, humidity and solar radiation intensity. The two buildings analyzed are located in the UNESP campus GuaratinguetáBrazil.

The results was positives, the green bricks provided the benefits mentioned above, showing that this type of construction can benefit society and the environment, encouraging their use.
\end{abstract}

\section{Key words}

Ecological Bricks, Green House, Energy Efficiency, Thermal Comfort.

\section{Introduction}

Currently, to minimize the environmental impacts caused by construction, professionals in this area seek using materials and resources that cause less environmental degradation. The eco-brick, made of cement, water and soil, is the most appropriate material and is being used for this purpose. It has several benefits compared to conventional brick, such: material savings, reduced construction time, is easy to produce and can be done at the construction place and don't consume fuel in the manufactur, by dispensing burning.
These ecological bricks have two holes in your structure (Fig 1) that provides some other important benefits: thermal stability, combat the humidity, economy in construction, acoustic properties, structural efficiency, reduction of power consumption and ease of electrical installations and hydraulic housing. In addition, their raw material, soil, is an abundant material on the planet.

This type of brick fits into the sustainable tripod, which consists of the features: social, economical and environmental. They spends $1 / 4$ of energy in its production process compared to ceramic bricks, and doesn't emit any type of waste to the environment, also the cost of the construction will be between 40 to $50 \%$ cheaper if you use the eco-bricks.

These bricks are used since the first decade of the 20th century in the United States and the pioneering research on this material are of 1935, made along the PCA Portland Cement Association. Starting in 1960, the soilcement began to have several scientific studies and began to dissemination in Brazil by IPT - Technological Research Institute of São Paulo and the ABCP - Brazilian Association of Portland Cement.

Tropical countries are great places for green buildings due to high incidence of solar radiation, heat and humidity. The benefits of green bricks can be clearly seen in the aspect of maintaining a pleasant temperature inside the building and avoid moisture on the walls of the house.

Knowing these benefits, and having a construction already completed on the campus of UNESP Guaratinguetá (Fig 2), was done this project with the objective of studying, perform measurements and analyze the parameter of thermal comfort of this construction, compared with a conventional construction (Fig 3), also situated on the campus of UNESP Guaratinguetá.

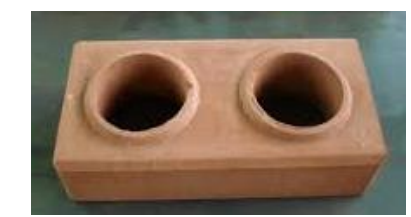

Fig. 1 Structure of Ecological Brick 


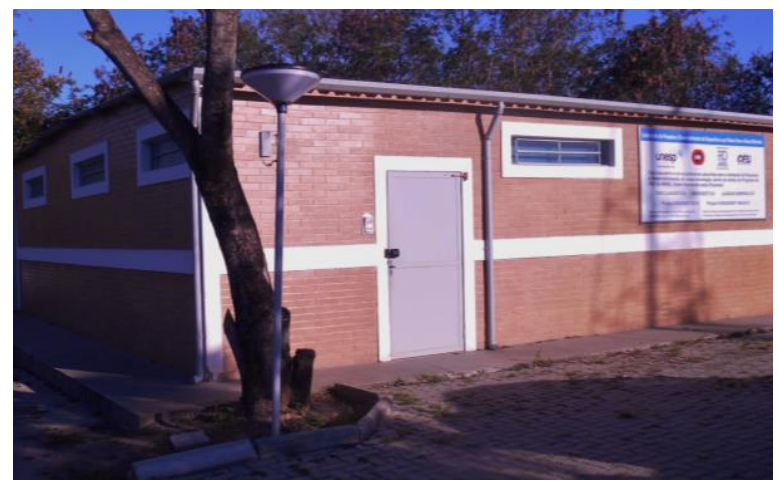

Fig. 2 House built with bricks soil cement.

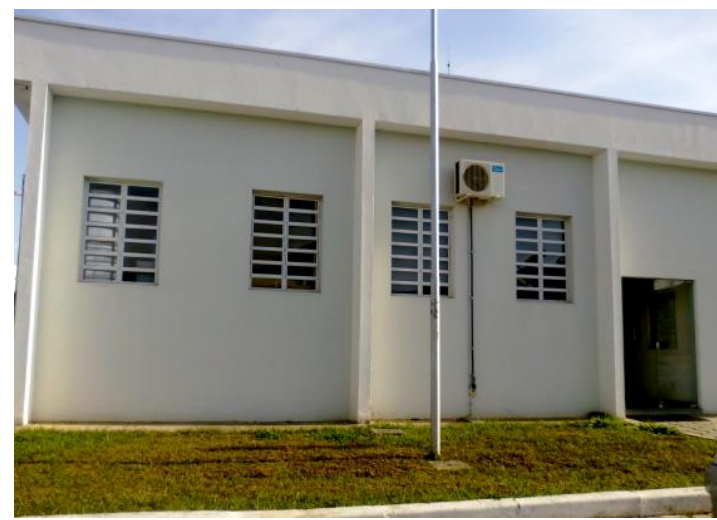

Fig. 3 House built with conventional bricks.

\section{Objectives}

The present project aims to study, check and analyze the internal and external temperature of the ambient, also the temperature of the bricks, of the house built with green bricks and the house made of conventional bricks, to compare and show benefits of using the green bricks.

\section{Materials and Methodology}

All the resources for the implementation of this project are located in the Center of Renewable Energy, situated at the Faculty of Engineering of Guaratingueta - UNESP. They are:

- A house of $102 \mathrm{~m}^{2}$, with wall height $2,8 \mathrm{~m}$ consists of kitchen, laundry area and 4 convenient, made of green bricks (Fig. 1);

- Temperature meter;

- Moisture meter;

- Density meter solar power;

- Anemometer;

- A house of $269 \mathrm{~m}^{2}$, with wall height $4,0 \mathrm{~m}$ consists of kitchen, bathrooms, and 7 convenient, made of conventional bricks (Fig. 3).

The instrumentation of the house located in the Faculty of Engineering of Guaratingueta was made, using gauges previously mentioned, to collect internal and external temperature of the two houses and the internal and external temperature of the bricks, speed of the winds, intensity of solar radiation and humidity on different days, in order to compare the results obtained.

These data were collected in differents days in a period of six months.

\section{Results}

Through the instrumentation made, were obtained different results, as showing in Table 1 and Graphic 1.

Table 1 - Information collected in the house built with green bricks and the conventional construction.

\begin{tabular}{|c|c|c|c|c|}
\hline Day & \multicolumn{2}{|c|}{$20 / 10 / 2014$} & \multicolumn{2}{|c|}{$22 / 10 / 2014$} \\
\hline Building & Ecological & Conventional & Ecological & Conventional \\
\hline Season & Spring & Spring & Spring & Spring \\
\hline Time & $8 \mathrm{~h} 50$ & 9h10 & $15 \mathrm{~h} 35$ & $16 \mathrm{~h}$ \\
\hline $\begin{array}{c}\text { Internal Ambient } \\
\text { Temperature } \\
\left({ }^{\circ} \mathrm{C}\right)\end{array}$ & 25,20 & 25,20 & 25,70 & 23,70 \\
\hline $\begin{array}{c}\text { External } \\
\text { Ambient } \\
\text { Temperature } \\
\left({ }^{\circ} \mathrm{C}\right)\end{array}$ & 22,30 & 23,20 & 24,00 & 25,40 \\
\hline $\begin{array}{c}\text { Wind Speed } \\
(\mathrm{m} / \mathrm{s})\end{array}$ & 0,3 & 0,5 & 1,7 & 1,4 \\
\hline $\begin{array}{c}\text { Solar Radiation } \\
\left(\mathrm{W} / \mathrm{m}^{2}\right)\end{array}$ & 150,8 & 177,4 & 362,3 & 400,8 \\
\hline Humidity & \multicolumn{2}{|c|}{$55 \%$} & \multicolumn{2}{|r|}{$48 \%$} \\
\hline $\begin{array}{c}\text { Internal Brick } \\
\text { Temperature } \\
\left({ }^{\circ} \mathrm{C}\right)\end{array}$ & 24,30 & 25,60 & 24,90 & 26,30 \\
\hline $\begin{array}{c}\text { External Brick } \\
\text { Temperature } \\
\left({ }^{\circ} \mathrm{C}\right)\end{array}$ & 22,40 & 23,40 & 25,20 & 26,40 \\
\hline
\end{tabular}

Table 2 - Information collected in the house built with green bricks and the conventional construction.

\begin{tabular}{|c|c|c|c|c|}
\hline Day & \multicolumn{2}{|c|}{$29 / 10 / 2014$} & \multicolumn{2}{|c|}{$03 / 11 / 2014$} \\
\hline Building & Ecological & Conventional & Ecological & Conventional \\
\hline Season & Spring & Spring & Spring & Spring \\
\hline Time & $15 \mathrm{~h} 30$ & $16 \mathrm{~h}$ & $8 \mathrm{~h} 50$ & $9 \mathrm{~h} 40$ \\
\hline $\begin{array}{c}\text { Internal } \\
\text { Ambient } \\
\text { Temperature } \\
\left({ }^{\circ} \mathrm{C}\right)\end{array}$ & 28,10 & 28,00 & 24,00 & 26,40 \\
\hline $\begin{array}{c}\text { External } \\
\text { Ambient } \\
\text { Temperature } \\
\left({ }^{\circ} \mathrm{C}\right) \\
\end{array}$ & 36,10 & 36,00 & 23,50 & 28,00 \\
\hline $\begin{array}{c}\text { Wind Speed } \\
(\mathrm{m} / \mathrm{s})\end{array}$ & 1,0 & 1,0 & 1,5 & 1,4 \\
\hline $\begin{array}{c}\text { Solar Radiation } \\
\qquad\left(\mathrm{W} / \mathrm{m}^{2}\right)\end{array}$ & 996,1 & 989,0 & 589,0 & 857,0 \\
\hline Humidity & \multicolumn{2}{|c|}{$25 \%$} & \multicolumn{2}{|c|}{$55 \%$} \\
\hline $\begin{array}{c}\text { Internal Brick } \\
\text { Temperature } \\
\left({ }^{\circ} \mathrm{C}\right)\end{array}$ & 28,30 & 29,00 & 28,50 & 26,50 \\
\hline $\begin{array}{c}\text { External Brick } \\
\text { Temperature } \\
\left({ }^{\circ} \mathrm{C}\right)\end{array}$ & 43,10 & 39,30 & 26,00 & 29,50 \\
\hline
\end{tabular}




\begin{tabular}{|c|c|c|c|c|}
\hline Day & \multicolumn{2}{|c|}{$06 / 11 / 2014$} & \multicolumn{2}{|c|}{ 10/11/2014 } \\
\hline Building & Ecological & Conventional & Ecological & Conventional \\
\hline Season & Spring & Spring & Spring & Spring \\
\hline Time & $15 \mathrm{~h}$ & $15 \mathrm{~h} 30$ & $14 \mathrm{~h} 30$ & $14 \mathrm{~h} 45$ \\
\hline $\begin{array}{c}\text { Internal } \\
\text { Ambient } \\
\text { Temperature } \\
\left({ }^{\circ} \mathrm{C}\right)\end{array}$ & 28,00 & 28,00 & 26,30 & 26,00 \\
\hline $\begin{array}{c}\text { External } \\
\text { Ambient } \\
\text { Temperature } \\
\left({ }^{\circ} \mathrm{C}\right) \\
\end{array}$ & 34,70 & 35,00 & 30,00 & 31,50 \\
\hline $\begin{array}{l}\text { Wind Speed } \\
(\mathrm{m} / \mathrm{s})\end{array}$ & 0,9 & 1,0 & 1,4 & 1,6 \\
\hline $\begin{array}{l}\text { Solar Radiation } \\
\qquad\left(\mathrm{W} / \mathrm{m}^{2}\right)\end{array}$ & 885,1 & 940,0 & 894,0 & 1202,0 \\
\hline Humidity & \multicolumn{2}{|c|}{$52 \%$} & \multicolumn{2}{|c|}{$40 \%$} \\
\hline $\begin{array}{c}\text { Internal Brick } \\
\text { Temperature } \\
\left({ }^{\circ} \mathrm{C}\right)\end{array}$ & 26,10 & 28,00 & 25,20 & 28,00 \\
\hline $\begin{array}{c}\text { External Brick } \\
\text { Temperature } \\
\left({ }^{\circ} \mathrm{C}\right)\end{array}$ & 34,50 & 35,00 & 31,00 & 36,00 \\
\hline
\end{tabular}

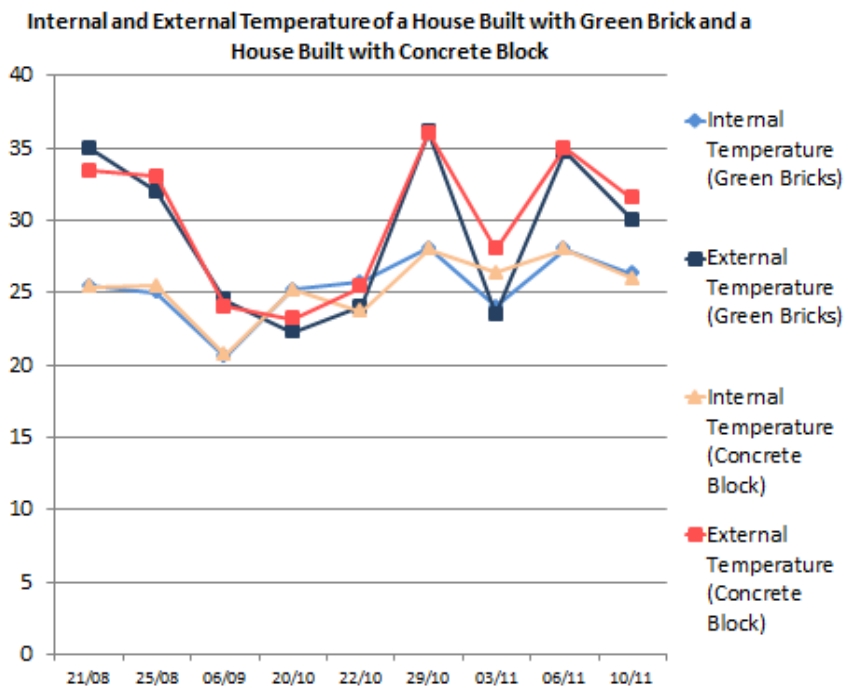

Graphic 2 - Information collected in the house built with green bricks and the conventional construction.

\begin{tabular}{|c|c|c|c|c|}
\hline Day & \multicolumn{2}{|c|}{$17 / 11 / 2014$} & \multicolumn{2}{|c|}{$12 / 01 / 2014$} \\
\hline Building & Ecological & Conventional & Ecological & Conventional \\
\hline Season & Spring & Spring & Summer & Summer \\
\hline Time & 9h15 & $9 \mathrm{~h} 30$ & $9 \mathrm{~h}$ & $9 \mathrm{~h} 30$ \\
\hline $\begin{array}{c}\text { Internal } \\
\text { Ambient } \\
\text { Temperature } \\
\left({ }^{\circ} \mathrm{C}\right)\end{array}$ & 24,30 & 21,80 & 28,40 & 28,80 \\
\hline $\begin{array}{c}\text { External } \\
\text { Ambient } \\
\text { Temperature } \\
\left({ }^{\circ} \mathrm{C}\right)\end{array}$ & 21,00 & 23,00 & 29,80 & 32,00 \\
\hline $\begin{array}{c}\text { Wind Speed } \\
(\mathrm{m} / \mathrm{s})\end{array}$ & 1,9 & 0,9 & 0,9 & 1,0 \\
\hline $\begin{array}{c}\text { Solar Radiation } \\
\left(\mathrm{W} / \mathrm{m}^{2}\right)\end{array}$ & 285,0 & 870,0 & 870,0 & 953,0 \\
\hline Humidity & \multicolumn{2}{|c|}{$48 \%$} & \multicolumn{2}{|c|}{$55 \%$} \\
\hline $\begin{array}{c}\text { Internal Brick } \\
\text { Temperature } \\
\left({ }^{\circ} \mathrm{C}\right)\end{array}$ & 24 & 25,1 & 30,7 & 31,2 \\
\hline $\begin{array}{c}\text { External Brick } \\
\text { Temperature } \\
\left({ }^{\circ} \mathrm{C}\right)\end{array}$ & 23,3 & 24,5 & 31,5 & 31,5 \\
\hline
\end{tabular}

Internal and External Temperature of the Green Bricks and the Concrete Blocks

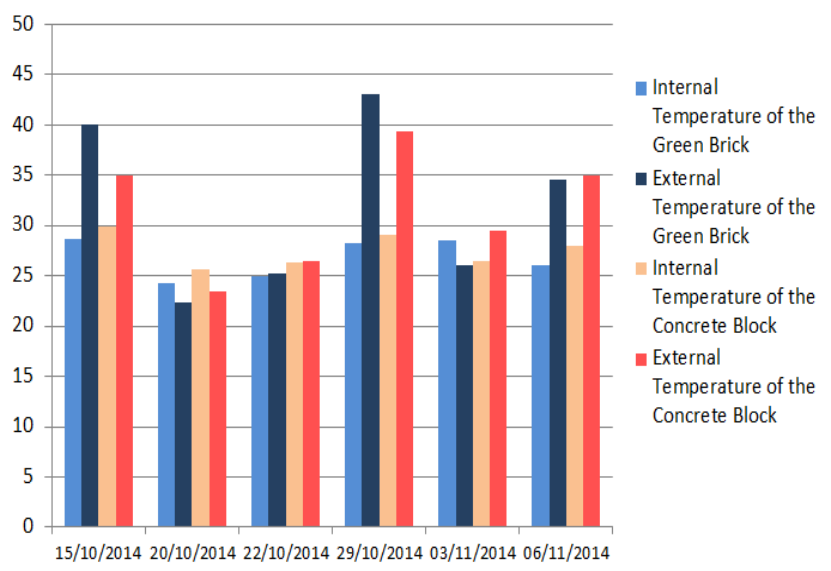

Graphic 1 - Information collected in the house built with green bricks and the conventional construction.

\section{Conclusion}

With the results, it was verified that the constructions made with ecological bricks really provide many benefits, being shown in this project that the green bricks, indeed, provide a greater thermal insulation, compared with the conventional construction made bricks.

It is known that a house with greater right foot, provides a cooler environment . In the case of this study, the right foot of a house built with concrete blocks is greater than the right foot home built with green bricks, and even then, the house with ecological bricks provides better insulation compared to conventional construction .

It should be borne in mind that the measurements were obtained at times with a small difference, which sometimes turned out to be variations of solar radiation and wind speed, temperature influencing the results.

Also, these green bricks reduce spending and lower environmental impact, because they don't need to be burn to became resistent, hindering the logs burning, thereby avoiding deforestation.

These bricks are easy to produce and has materials easily found. It is suitable for construction of affordable housing and rural buildings, which has abundant land for the production of such bricks.

The concrete block is an extremely important and fundamental material in construction, however, with this study, it is found that the concrete block provides less insulation than the ecological bricks provide.

\section{References}

[1] ABNT, 1994a. Brazilian Standard NBR 10836 e SoilCement Bricks: Determination of Compressive Strength and Water Absorption. Brazilian Association of Technical Standards. 
[2] Mbnta, A. (1989,,). Durability of soil-cement for building pur- poses. Into'national Conference on th mortcl strateg for Tech DevelopmenL Book of abstracts, No. 77, 1989, Aug

[3] Portland Cement AssoclaUon, PCA (1956). Soil Cement Construction Handbook, PCA, Cldcago III 1956.

[4] GIVONI, Baruch. Comfort Climate Analysis and Building Design Guidelines. Energy and Buildings, v. 18, n. 1, p. 11-23, 1992.

[5] Miranda, L.A., Alvarenga, R.C.S.S., Junior, P.C.M.P., Junior, E.D.P., Carvalho, C.A.B.,Fassoni, D.P., Couto, L.G., 2011. Evaluation of grits as the building materials inthe production of soil-cement bricks. Rev. Árvore 35, $1335 \mathrm{e} 13$

[6] Freire, J. W., Beraldo A. L. Tecnology and alternative materials of buildings. Campinas, SP: Editora da Unicamp, 2003.

[7] CEPED. Primer Construction with Soil-Cement. Camaçari: Center of Development and Research.

[8] ABCP Streets of Soil-Cement; Buildings Practics. São Paulo: Cement Portland Brasilian Association (BT- 86), 1984.

[9] Teixeira, F. J. Soil-Cement Aplications in small urban areas. São Paulo: ABCP (BT-109), 1989. 